\title{
Telaah atas Karya Tafsir di Indonesia: Studi atas Tafsir al-Bayan Karya Tm. Hasbi al-Siddiqi
}

\author{
Surahman Amin \\ STAIN Sorong-Papua. \\ Ferry Muhammadsyah Siregar \\ Universitas Gadjah Mada, Yoyakarta. \\ Email:ferary26@yahoo.com
}

\begin{abstract}
This article discusses the characteristic of TM Hasbi as-Siddiqi's Tafsir al-Bayan, its methodology and influence to the society. Indonesian Muslims' reception toward this tafsir is also discussed. This article suggests that the the methodology of thre Quranic interpretation utilized in tafisr al-Bayan is analytical method or tahlili. This tafsir also puts emphasis on Islamic jurisprudence (figh), partly because the author of the Tafsir is reknowned as a professor in Islamic Law. Keywords: Tafsir al-Bayan, exegesis methods, Indonesia
\end{abstract}

\section{ABSTRAK}

Tulisan ini menjelaskan tentang bagaimana wujud Tafsir al-Bayan karya TM. Hasbi al-Siddiqi dan menjawab pertanyaan seputar identitas dan metode penafsiran karya tafsir ini, pengaruh dan sambutan masyarakat terhadapnya, serta kedudukannya dalam sejarah perkembangan tafsir di Indonesia. Dalam paparannya, tulisan ini menggunakan teori tafsir. Tulisan ini menemukan bahwa tafsir ini menggunakan metode penafsiran yang bersifat analitis, yakni metode tafsir al-tahlili. Adapun bentuk penulisannya bercorak fighi (hukum), sesuai dengan pengarangnya yang merupakan guru besar di bidang hukum Islam. Kata kunci: Tafsir al-Bayan, metode tafsir, Indonesia

\section{PENDAHULUAN}

Tafsir al-Qur'an merupakan kegiatan ilmiah yang paling tinggi dan utama di antara ilmu-ilmu keislaman lainnya. Al-Ragib al-Asfahani (w.502 H.) sebagaimana yang dikutip oleh al-Suyuti (w. $911 \mathrm{H}$ ) memberi argumentasi mengenai keutamaan ini dari tiga sudut pandang; pertama dari segi materi, karena tafsir adalah kalamullah yang merupakan sumber segala kemuliaan. Kedua, dari segi tujuan bahwa tafsir merupakan pegangan umat Islam dalam mengarungi kehidupan dunia dan akhirat. Ketiga, dari segi kebutuhan yang amat mendesak, sebab untuk mencapai kesempurnaan dalam urusan agama dan dunia dibutuhkan ilmu-ilmu syariat dan pengetahuan agama dan kesemuanya hanya bisa dicapai dengan menguasai kitab suci al-Qur'an. Bahkan lebih lanjut al-Suyuti menyimpulkan bahwa mempelajari tafsir al-Qur'an merupakan fardu kifayah. ${ }^{1}$

Menurut keyakinan kaum muslimin, al-Qur'an adalah kitab suci yang merupakan petunjuk bagi umat manusia, ${ }^{2}$ 
khususnya bagi mereka yang beriman ${ }^{3}$ dan bertaqwa, ${ }^{4}$ di mana pun dan kapan pun mereka hidup. Atau dengan kata lain, alQur'an tersebut berlaku untuk semua tempat dan zaman, serta dalam situasi dan kondisi apa pun. Karena itu, hendaknya al-Quran diamalkan dalam kehidupan, dan agar pengamalannya dapat terwujud, maka diperlukan upaya penafsiran terhadapnya secara baik dan benar.

Penafsiran terhadap al-Qur'an, telah dimulai sejak Islam diturunkan dan Nabi Muhammad saw. bertindak sebagai al-mufassir al-awwal (penafsir pertama dan utama).

Kemudian, dilanjutkan oleh para sahabatnya, para tabi'in, atba' al-tabi'in dan generasigenerasi sesudahnya sampai masa kini. Bahkan, upaya seperti ini masih tetap berlanjut sampai masa-masa mendatang.

Penafsiran terhadap al-Qur'an telah mengalami perkembangan yang sangat siginifikan. Hal ini ditandai dengan lahirnya berbagai karya tafsir, baik pada masa almutaqaddimin, ${ }^{5}$ maupun pada masa almuta'akhirin ${ }^{6}$ dan masa al-asr (modern) ${ }^{7}$ sekarang ini. Karya-karya tafsir tersebut, masing-masing memiliki metode, corak dan teknik interpretasi yang berbeda-beda. Bahkan, sistematika peyusunan dan jenis bahasa yang digunakan juga berbeda-beda.

Menurut Howard M. Federspiel, sebagaimana yang dikutip oleh Islah Gusmian dan Ferry Muhammadsyah Siregar bahwa salah satu karya tafsir yang muncul pada masa al-asr (modern) dan mewakili tafsir generasi ketiga di Indonesia adalah Tafsir al-Bayan, karya TM. Hasbi al-Siddiqi. ${ }^{8}$

Karya tafsir ini, selesai ditulis pada tahun 1966 dan sistematika penyusunanya terdiri atas dua jilid, serta jenis bahasa yang digunakan dalam menafsirkan ayat-ayat al-
Qur'an adalah bahasa Indonesia. Pada tahun yang sama, karya tafsir ini dicetak oleh Penerbit al-Ma'arif Bandung. Kemudian dicetak lagi oleh penerbit Pustaka Rizki Putra Semarang pada tahun 2002. Kehadiran tafsir ini bertujuan untuk memahami al-Qur'an secara komprehensif.

Tulisan ini menjelaskan tentang bagaimana wujud Tafsir al-Bayan karya TM. Hasbi al-Siddiqi dan menjawab pertanyaan seputar biografi penulis Tafsir al-Bayan, identitas dan metode penafsiran Tafsir alBayan, pengaruh dan sambutan masyarakat terhadap Tafsir al-Bayan, serta kedudukan Tafsir al-Bayan dalam sejarah perkembangan tafsir di Indonesia.

\section{BIOGRAFI T.M. HASBI AL-SIDDIOQI}

T.M. Hasbi al-Siddiqi, (selanjutnya disebut T.M. Hasbi) bernama lengkap Prof. Dr. Honoris Causa (HC) Tengku Muhammad Hasbi al-Siddiqi,, ${ }^{9}$ lahir di Lhokseumawe, Aceh Utara, pada 10 Maret 1904. Ayahnya bernama al-Hajj Tengku Muhammad Husen ibn Muhammad Su'ud, menduduki jabatan Qadhi (hakim) Chik Maharaja Mangkubumi di Simeuluk Samalanga Aceh, sedangkan Ibunya bernama al-Hajjah Tengku Amrah, adalah putri Tengku Abdul Aziz. Paman beliau yang lain bernama Teungku Tulot yang menduduki jabatan pertama kali pada masa awal pemerintahan Sri Maharaja Mangkubumi. ${ }^{10}$

T.M. Hasbi, pada awalnya belajar ilmu qiraah dan tajwid serta dasar-dasar tafsir dan fiqhi pada ayahnya sendiri, dan dalam usianya 8 (delapan) tahun ia telah khatam mengaji alQur'an. Setelah memperoleh ilmu-ilmu keagamaan dari ayahnya, ia belajar di pesantren-pesantren. Pada tahun 1912, ia belajar di pesantren Tengku Piyeung; pada 
tahun 1913 di pesantren Bluk Bayu; pada tahun 1914, di pesantren Blang Kabu; pada tahun 1916, di pesantren Tengku Idris; pada tahun 1918 di pesantren Tengku Chik Hasan. Selanjutnya, pada tahun 1920 dari Tengku Chik Hasan Kruengkale. TM. Hasbi memperoleh syahadah sebagai pengakuan dan pernyataan bahwa ilmunya telah cukup dan berhak untuk membuka pesantren atau dayah. ${ }^{11}$ Berdasarkan perjalanan sejarah pendidikannya ini, maka diketahui bahwa TM. Hasbi telah menghabiskan masa-masa mudanya di lingkungan pesantren. Pada sisi lain, pengetahuan Islam yang telah diperolehnya tersebut, membuatnya cerdas dan dinamis untuk ia kembangkan.

Pada tahun 1926, T.M. Hasbi bersama Syaikh al-Kalali (Penyusun Kamus Bahasa Arab-Indonesia) berangkat ke Surabaya, untuk melanjutkan pendidikan di Perguruan al-Irsyad. Setelah di tes, ia dapat diterima di jenjang takhassus. ${ }^{12}$ Setelah belajar di alIrsyad, ia mengembangkan dan memperkaya diri dengan ilmu melalui belajar sendiri (otodidak). Selain mempelajari ilmu-ilmu keislaman dan bahasa Arab dengan baik, ia juga mempelajari bahasa Belanda dari seorang warga Belanda yang belajar bahasa Arab darinya, sehingga dengan mudah mudah mengakses segala bentuk informasi dari media massa yang pada masa itu dikuasai oleh pemerintahan Hindia-Belanda.

Pada tahun 1933 T.M Hasbi tiba di Kutaraja, kemudian bergabung dengan organisasi Nadi Ishlah al-Islam yang merupakan organisasi pembaru di kota tersebut dan pada saat yang bersamaan beliau juga dinobatkan sebagai pimpinan redaksi Soeara Atjeh. Disamping itu beliau juga mengajar pada kursus-kursus yang diselenggarakan oleh JIB (Jong Islamietien
Bond) Aceh dan menjadi pengajar pada sekolah HIS dan MULO Muhammadiyah. T.M Hasbi pernah memimpin Ormas Muhammadiyah Aceh sampai bulan Maret 1946. Selanjutnya T.M hasbi disekap oleh Gerakan Revolusi Sosial yang gerakkan oleh PUSPA (Persatoean Oelama Seloeroeh Atjeh, didirikan pada tahun 1939), dimana organisasi ini melihat bahwa Muhammdiyah Aceh di bawah kepemimpinan T.M Hasbi merupakan saingan utama dalam pengembangan ajaran Islam. Akibat penyekapan yang misterius ini T.M Hasbi harus mendekam di dalam penjara di Kamp Burnitelog Aceh selama kurang lebih satu tahun, kemudian pada pertengahan tahun 1948 T.M Hasbi di dibebaskan dan diizinkan pulang ke Lhoksumawe akibat desakan Pimpinan Pusat Muhammadiyah melalui Sutan Mansur dan Pemerintah Pusat melalui Wakil Presiden Moehammad Hatta, namun masih berstatus tahanan kota, barulah pada Februari 1947 Status tahanan kota T.M Hasbi dicabut dan dinyatakan bebas Residen Aceh.

Selama di Aceh T.M Hasbi selain menjadi pengajar di kursus-kursus dan sekolah Muhammadiyah beliau juga memimpin SMI (Sekolah Menengah Islam), selain itu beliau juga aktif berdawah lewat Masyumi dimana T.M. Hasbi menjadi Ketua Cabang Masyumi Aceh Utara. Pada 20-25 Desember 1949 diadakan Kongres Muslimin Indonesia (KMI) di Yogyakarta dimana T.M Hasbi mewakili Muhammadiyah dan Ali Balwi mewakili PUSPA. Pada kongres tersebut T.M Hasbi menyampaikan Makalah dengan judul Pedoman Perdjuangan Islam Mengenai Soal Kenegaraan, disinilah oleh Abu Bakar Aceh memperkenalkan T.M Hasbi kepada Wahid Hasyim (Menteri Agama pada masa itu) dan K. Fatchurrahman Kafrawy. Setahun 
kemudian setelah perkenalan tersebut Menteri Agama memanggil T.M Hasbi untuk menjadi dosen pada PTAIN yang akan didirikan, sehingga pada Januari tahun 1951 T.M Hasbi berangkat ke Yogyakarta dan menetap di sana mengkonsentrasikan diri dalam bidang pendidikan. ${ }^{13}$

Selanjutnya, pada tahun 1960 TM. Hasbi memperoleh dua gelar Doktor Honoris Causa sekaligus. Dr. HC, pertama ia peroleh dari Unisba (Universitas Islam Bandung) dan Dr. HC yang kedua ia terima dari PTAIN Sunan Kalijaga Yogyakarta, ${ }^{14}$ yang sekarang ini telah berubah status menjadi UIN Sunan Kalijaga. ${ }^{15}$ Dengan penganugrahan Dr. HC ini, T.M. Hasbi kemudian mengajar beberapa mata kuliah di kedua Perguruan Tinggi Tersebut.

Pada tahun 1966, TM. Hasbi dikukuhkan sebagai Guru Besar di PTAIN Sunan Kalijaga (sekarang UIN) dalam bidang keilmuan Hadis dan Hukum Islam. ${ }^{16}$ Selanjutnya, ia menjabat Dekan pada Fakultas Syariah sampai tahun 1972.

T.M. Hasbi juga mengajar dan memangku jabatan struktural pada Perguruan Tinggi Perguruan Tinggi Islam Swasta. Dalam hal ini, pada tahun 1961 sampai 1971, dia juga menjabat Rektor Universitas al-Irsyad Surakarta; pada tahun 1964, ia mengajar di Universitas Islam Indonesia (UII) di Yogyakarta; pada tahun 1967 ia mengajar dan menjabat Dekan Fakultas Syariah Universitas Islam di Sultan Agung di Semarang. ${ }^{17}$

Selanjutnya, pada tahun 1975 TM. Hasbi diundang oleh Menteri Agama RI untuk menunaikan ibadah haji. Namun dalam waktu yang bersamaan, ia menjalani rawat inap (opname) di Rumah Sakit Islam Jakarta dan di rumah sakit inilah ia meninggal, tepatnya pada hari Senin, 9 Desember 1975, pukul $17.45 .{ }^{18}$ Dengan demikian, jika kembali ditelusuri tahun kelahirannya (1904) dan tahun wafatnya (1975), maka TM. Hasbi berpulang ke rahmatullah dalam usia 71 tahun. Jenazahnya dimakamkan di Pemakaman Keluarga IAIN Syarif Hidayatullah Ciputat Jakarta (sekarang UIN Syarif Hidayatullah). Pada upacara pelepasan jenazah, turut memberikan sambutan Buya Hamka (almarhum), dan pada saat pemakaman, dilepas oleh Mr. Moh. Roem ${ }^{19}$

TM. Hasbi dikenal sebagai ulama yang produktif menuliskan ide pemikiran keislamannya. Karya tulisnya mencakup berbagai disiplin ilmu keislaman. Menurut catatan, karya yang berbentuk buku berjumlah 73 judul (142 jilid). Sebagian besar karyanya adalah tentang fiqhi (36 judul). Bidang bidang lainnya adalah hadits (8 judul), tafsir (6 judul), tauhid; ilmu kalam (5 judul). Dan selebihnya adalah tema-tema yang bersifat umum. ${ }^{20}$ Selain menulis buku beliau juga aktif menulis dalam bentuk artikel. Tercatat sekitar 50 artikel dalam bidang tafsir, hadith, fiqh dan pedoman ibadah dan beliau hasilkan. Diantara karya ilmiah yang beliau tulis adalah; dalam bidang Tafsir dan Ilmu al-Qur'an, ia menulis Tafsir al-Nur dan Tafsir al-Bayan; dalam bidang Hadis dan Ilmu Hadis, ia menulis Sejarah dan Pengantar Ilmu Hadia dan 2002 Mutiara Hadis; dalam bidang Fiqh, ia menulis Sejarah Peradilan Islam dan Pengantar Hukum Islam; dalam bidang Tauhid/Kalam, ia menulis Peladjaran Tauhid dan Hakikat Islam dan Unsur-Unsur Agama. Di samping itu, ia juga menulis buku agama yang bersifat umum misalnya al-Islam dan Pedoman Zikir dan Doa. Tentu saja, masih banyak karya-karya lainnya, baik berupa artikel, makalah-makalah dan selainnya yang tidak sempat penulis sebut satu persatu di sini. 
Dengan karya-karyanya tersebut, maka dapat diketahui TM. Hasbi adalah sosok ulama dan intelektual yang sangat produktif menulis.

\section{MENGENAL TAFSIR AL-BAYAN Identitas Tafsir al-Bayan}

Sepanjang hidupnya T.M. Hasbi

menghasilkan dua tafsir yang terkenal yaitu, yakni Tafsir al-Nur ${ }^{21}$ yang terbit pada tahun 1960; dan Tafsir al-Bayan yang penulisannya selesai tahun $1966,{ }^{22}$ juga pada tahun ini pertama kali dicetak oleh penerbit al-Ma'arif Bandung. Selanjutnya pada tahun 2002 atas permintaan dari masyarakat di cetak untuk kedua kalinya oleh Pustaka Rizki Putra Semarang, dan kitab cetakan kedua yang penulis jadikan sebagai pedoman dalam mendeskripsikan karya tafsir ini.

Tafsir al-Bayan terdiri atas dua jilid dan setiap jilidnya berisi 15 juz. Jilid I memuat tafsiran ayat-ayat al-Qur'an mulai juz I sampai juz 15 (dari Surah al-Fatihah sampai Surah alKahfi ayat 74), sedangkan jilid II memuat tafsiran ayat-ayat al-Qur'an mulai 16 sampai juz 30 (Surah al-Kahfi ayat 75 sampai akhir surah al-Nas). Dengan demikian, karya tafsir ini memuat terjemah dan tafsir ayat-ayat alQur'an secara keseluruhan, yakni 114 surah.

Format penyusunan Tafsir al-Bayan pada jilid I, terdiri atas atas 674 halaman. Secara terstruktur dimulai dari halaman vii pengantar dari penerbit, halaman ix, sekapur sirih dari penyunting yaitu putra T.M. Hasbi yaitu H.Z. Fuad Hasbi al-Siddiqi. Selanjutnya pada halaman xi-xii terdapat kata pengantar dari sang mufassir T.M. Hasbi. Halaman xiiixv terdapat "Khiththah Penerjemahan" yang dijadikan pedoman dalam menerjemahkan al-Qur'an. Sedangkan "Daftar Isi” terdapat pada halaman xix-xlii.

Mengenai isi pembahasan pendahuluan tafsir ini yang diberi lebel "Muqaddimah" secara berturut-turut adalah sebagai berikut :

a) Bab I, "Al-Qur'anul Majid" (h. 1-21).

b) Bab II, "Hikmah al-Qur'an Diturunkan Berangsur-Angsur" (h. 23-24).

c) Bab III, "Hukum-Hukum Yang Dikandung al-Qur'an Serta Uslub-Uslub (Susunan)

Dakwah al-Qur'an”, (h. 25-32).

d) Bab IV, "Segi-Segi Kemukjizatan alQur'an”, (h. 33-39).

e) Bab V, "Sejarah Nuzul al-Qur'an", (h. 4146).

f) Bab VI, Sejarah Mengumpul al-Qur'an”, (h. 47-57).

g) Bab VII, "Penafsiran al-Qur'an", (h. 59-70).

h) Bab VIII, "Hukum Menerjemahkan alQur'an”, (h. 71-72).

i) Bab XI, "Teori Nasakh dalam al-Qur'an", (h. 73-78).

j) Bab X, "Adab Membaca al-Qur'an dan Mendengarnya", (h. 79-85).

k) Bab XI, "Sekelumit Tentang Pembahasan Qira'ah”, (h. 87-91)

Selanjutnya untuk terjemahan dan penafsiran al-Qur'an dimulai lagi dari halaman 1 yang merupakan halaman sampul yang berjudul "Tafsir Al-bayan Juz I." Sebelum masuk pada bagian inti atau penerjemahan dan penafsiran, ada bagian penjelasan tentang juz yang akan dibahas, berupa hizib (bagian) dari ayat-ayat dan setiap hizib dibagi ke dalam beberapa rubu' (sub bagian).

Pada halaman 3, baru dimulai penafsiran ayat-ayat pada juz 1 sampai halaman 54 , Untuk juz 2 dan seterusnya sampai ke juz 15 dalam jilid I ini, masing-masing memiliki hizib yang berbeda-beda. Banyak dan atau sedikitnya jumlah hizib, tergantung pula dari prosentase banyak dan atau sedikitnya jumlah 
ayat dalam setiap Juz. Jilid I ini berakhir pada halaman 674. Selanjutnya (tanpa halaman) dicantumkan diakhir lembaran "Tanda Tashhih" dengan No: BD.III/TI.02.1/244/ 2002 yang ditandatangani oleh Panitia Pentashihan al-Qur'an yang diketuai oleh Haji Fadhl Abdurrahman Bafadal pada tanggal 28 Oktober 2002.

Kemudian, pada juz II lembarannya di mulai dari halaman vii-xxix yang merupakan "Daftar Isi". Selanjutnya sebelum dimulai penafsiran, sama halnya pada jilid I, ada keterangan tentang pembagian hizib Juz 16 (tanpa halaman). Setelah itu pada halaman 677 dimulailah penafsiran al-Qur'an Juz 16 yang ayatnya dimulai ayat 75 dari surah alKahfi. Begitu seterusnya sampai berakhir penafsiran Juz 30 pada halaman 1646. Adapun halaman 1647 sampai 1657 berisi glossary. Selanjutnya pada halaman 1659 . 1662 berisi "Sekilas Tentang Penulis." Dan diakhir Jilid II, seperti jilid I terdapat "Tanda Tashhih". Mengenai sistematika dan isi tafsiran jilid II ini, sama halnya dengan jilid I.

\section{Latar Belakang Sejarah Tafsir al-Bayan}

Latar belakang penulisan Tafsir al-Bayan, terinspirasi dari karya tafsir penulisnya yang pertama, yakni Tafsir al-Nûr yang mendahului Tafsir al-Bayan tersebut. Untuk lebih jelasnya, berikut ini dikutip pernyataan TM. Hasbi mengenai latar belakang penulisan Tafsir alBayan:

Dengan 'inayah Allah dan taufiq-Nya, setelah selesai menyusun tafsir al-Nur yang menerjemahkan ayat dan menafsirkannya, tertariklah pula hati saya menyusun al-Bayan ini. Di dalam menerjemahkan ayat dalam tafsir al-Nur, saya menempuh jalan cepat, jalan yang lazim ditempuh oleh penerjemahpenerjemah lain. Karenanya terjemahan ayat- ayat dalam tafsir al-Nur tidak menerjemahkan seluruh lafal, apalagi lafal-lafal yang harus diungkapkan.... maka setelah saya memperhatikan perkembangan terjemahan Alquran akhir-akhir ini, serta meneliti secara tekun terjemahan-terjemahan itu, nyatalah bahwa "banyak terjemahan kalimat" yang perlu ditinjau dan disempurnakan. Oleh karenanya, dengan memohon taufiq dari pada Allah Swt saya menyusun sebuah terjemah yang lain yang meliputi segala lafal, bahkan meliputi terjemah dari lafal-lafal yang diungkapkan menurut pendapat-pendapat ahli tafsir kenamaan. ${ }^{23}$

.... Tafsir al-bayan merupakan suatu terjemahan dari ma'na-ma'na Al-Qur'an yang lebih lengkap dari terjemahan-terjemahan yang telah ber-kembang dalam masyarakat dewasa ini. $^{24}$

Dari pernyataan TM. Hasbi di atas, maka dapat dijelaskan bahwa latar belakang penulisan Tafsir al-Bayan disebabkan oleh dua faktor: pertama, faktor Internal, yang dimaksud di sini adalah motivasi dari penulisnya sendiri untuk mengembangkan karya tafsirnya yang telah ia tulis sebelumnya. Dalam hal ini, TM. Hasbi menyadari bahwa karya tafsirnya yang berjudul Tafsir al-Nur masih perlu dikembangkan dan disempurnakan, khususnya dari aspek metodologi tafsir. Dalam aspek ini, Tafsir alNur yang mendahului Tafsir al-Bayan hanya merupakan karya tafsir yang secara metodologis menginterpretasikan ayat-ayat alQur'an secara singkat. Atau dengan kata lain, sebagian lafaz atau ayat di dalam Tafsir al-Nur tersebut tidak terinterpretasi secara tuntas. Karena itu, maka TM. Hasbi sebagai mufassir tertarik untuk lebih "mempertajam” makna lafa“-lafa" ayat al-Qur'an, dan ketertarikannya 
itu terwujud dengan lahirnya Tafsir al-Bayan. Kedua Faktor Eksternal, yang dimaksud di sini adalah motivasi yang bersumber dari tafsir-tafsir al-Qur'an di luar tafsir al-Nur. Dalam hal ini, T.M. Hasbi menyatakan bahwa terjemahan-terjemahan atau tafsirtafsir yang ada ketika itu, masih perlu ditinjau dan disempurnakan.

Terkait dengan keterangan di atas dan tanpa mengurangi kredibilitas karya-karya tafsir lainnya, dapatlah dikatakan bahwa Tafsir al-Bayan ini merupakan karya tafsir yang menafsirkan makna-makna al-Qur'an yang "lebih lengkap" dari pada karya-karya tafsir lainnnya pada masa itu. Atau dengan kata lain, Tafsir al-Bayan ini, tidak tertandingi kredibilitasnya oleh karya-karya tafsir lainnya yang telah disusun oleh mufassir-mufassir di Indonesia pada masa itu, tepatnya dalam kurun waktu tahun 1950-an sampai dengan 1970-an.

Mengenai latar belakang penamaan Tafsir al-Bayan, T.M.Hasbi tidak menjelaskan dengan pasti tentang penamaan ini. Tetapi menurut analisa penulis dinamakan demikian karena dalam tafsirnya sang mufassir setelah menerjemahkan ayat-ayat alQur'an, berusaha menjelaskan lafal ayat-ayat yang sulit dimengerti oleh masyarakat dengan penjelasan yang singkat dan padat.

\section{Metode Penafsiran Dan Corak Tafsir Al- Bayan}

Untuk mengetahui metode penafsiran dan metode penulisan yang terpakai dalam Tafsir al-Bayan, maka terlebih dahulu akan ditelusuri sistematika penafsirannya. Dalam hal ini T.M. Hasbi menyatakan berbagai langkah dan tahapan yakni:

Khiththah-khiththah (langkah dan tahapan) yang saya tempuh dalam menterjemahkan ayat (lafal) Al-Qur'an dan komentarkomentar ringkasnya, ialah :

a. Menterjemah ma'na lafal dan meterjemah kalimat-kalimat yang ditaqdirkan, baik di awal ayat, di pertengahannya, maupun di akhirnya.

b. Menterjemahkan kalimat-kalimat yang mempunyai dua terjemahan dengan lengkap, dengan menyebut terjemahan kedua dalam (.......).

c. Menterjemahkan lafal-lafal yang ditaqdirkan, atau yang merupakan kalimatkalimat pelancar, dalam dua streep -........

d. Menterjemahkan makna ayat yang dapat diterjemahkan lebih dari satu macam, lantaran berlainan I'rab dan sebagainya. Terjemahan yang kedua diletakkan dalam noot, diawali oleh perkataan: "dapat juga diterjemahkan .......".

e. Menerangkan pendapat-pendapat ulama di dalam memaknakan sesuatu ayat, atau kalimat yang berbeda-beda, ditempattempat yang saya pandang perlu dan penting diberi perhatian, karena kuat dalihnya. Hal ini saya sebut dalam note.

f. Menterjemahkan lafal-lafal sifat Allah swt yang sewazan "fa'ul" yang memfaedahkan "kebanyakan" dan "kesangatan" dengan mengawali terjemahannya dengan "yang sangat" atau "yang sangat banyak" atau "yang maha", seperti ghafûr = maha pengampun atau yang sangat pengampun atau yang banyak mengampun. Lafal-lafal sifat yang sewazan fa'il, yang memfaedahkan tsubut = tetap dan terus menerus, bukan menerangkan banyak atau sangat, saya awali terjemahannya dengan "yang senantiasa", atau "yang tetap". 25

$$
\text { dalam menterjemahkan sighah }
$$
mubalaghah dan sifat musyabbahah, saya memilih pendapat al-Imam Muhammad 
Abduh dalam mema'nakan sifat-sifat arRahman dan Ar-Rahim. Beliau berkata “ shigah-shigah yang sewazan "fa'lana", menunjukkan kepada suatu sifat perbuatan yang mengandung arti mubalaghah, seperti lafadh "jau'ana = sangat lapar". Sifat-sifat ini dipakai buat sifat-sifat yang mendatang, yakni; kadang-kadang ada, kadang tidak, seperti "atsyasana = yang sangat haus", "ghadbana = yang marah". Sighat-shigat "fail", menunjukkan kepada makna yang tetap (senantiasa ada pada) manusia. Sighat "fa'il", ialah seperti "a'lim = yang tetap mengetahui". "hakim = yang tetap mempunyai hikmah, atau yang senantiasa mengerjakan/menetapkan sesuatu sesuai dengan hikmah", "jamil = yang tetap indah", dan "halim = yang tetap dapat menahan amarah".

untuk membedakan antara ayatayat yang sebanding dengan ayat yang ada hubungannya dengan penafsiran ayat, maka ayat-ayat yang sebanding itu, diawali dengan: "ayat ini sebanding dengan ...." Sedang ayatayat yang ada hubungannya dengan tafsir ayat, diawali dengan "bacalah (perhatikanlah) ayat .......". Dalam menghadapi lafal-lafal yang musytarak (yang banyak maknanya) yang dipakai dalam berbagai perngertian, seperti kalimat haq, maka saya menterjemahkan dengan pengertian yang dimaksud pada tempatnya masing-masing. untuk tafsir dan penjelasan dari makna, saya letakkan dalam noot. ${ }^{26}$

Selanjutnya, sesuai dengan penelusuran penulis diketahui bahwa Tafsir al-Bayan dalam menjelaskan ayat-ayat, ia menerangkan tafsirnya dengan cara ringkas tapi padat; menerangkan ayat yang semakna dengannya; menerangkan ayat yang ada hubungan dengan penafsirannya (munasabah).
Dengan mencermati sistematika atau cara-cara yang ditempuh Tafsir al-Bayan dalam menafsirkan ayat-ayat al-Qur'an sebagai mana yang telah dipaparkan, maka dapat rumuskan metode penafsiran dan metode penulisan Tafsir al-Bayan, sebagai berikut.

\section{Metode Penafsiran}

Metode tafsir terdiri atas empat bentuk, yakni tahlili; ${ }^{27}$ ijmali; ${ }^{28}$ muqaran $^{29}$ dan maudhu'i. ${ }^{30}$ Bila keempat bentuk metode tafsir ini, dikaitkan dengan sistematika penafsiran Tafsir al-Bayan, maka dapat disimpulkan bahwa tafsir tersebut menggunakan metode tahlili. Pada awalnya penulis agak kesulitan menentukan metode yang digunakan oleh TM. Hasbi dalam menafsirkan al-Qur'an, tetapi setelah membaca kriteria penafsiran yang dijelaskan dalam khittahnya dan membaca ayat-ayat yang ditafsirkan, maka penulis cenderung memasukkan tafsir ini dalam kategori tafsir tahlili.

Metode tahlili, dikenal pula dengan istilah metode analitis. Dengan metode seperti ini, sang mufassir menjelaskan kandungan ayat dan menerangkan makna-makna yang tercakup di dalamnya sesuai keahlian dan kecenderungan mufassir yang menafsirkan ayat-ayat tersebut. ${ }^{31}$. Dalam hal ini, T.M. Hasbi dalam menjelaskan ayat-ayat al-Qur'an, ia menerangkan makna-makna ayat yang tercakup di dalamnya, dan menguraikannya secara runtut ayat demi ayat, surah demi surah sesuai dengan urutannya di dalam mushaf, yakni mulai dari surah al-Fatihah sampai surah al-Nas.

Ayat-ayat yang ditafsirkan oleh T.M. Hasbi tersebut dijelaskan pula aspek-aspek munasabah-nya, ${ }^{32}$ khususnya dalam hal munasabah antara "kata" dalam satu ayat 
dengan "kata" yang sama pada ayat lainnya dan atau pada surah lainnya. Misalnya, tafsiran kata "hudan" pada Q.S. al-Baqarah/2: 2 adalah; yang memberi petunjuk kepada orang-orang yang bersifat taqwa, oleh T.M. Hasbi mengkaitkannya dengan kata "hudan" pada QS. Yûnus/10: 57; juga "huda" pada Q.S. al-An'am/6: 90; juga kata "al-huda" pada QS. Fushilat/41: $17 .{ }^{33}$ Dengan tafsiran seperti ini, maka dapat dipahami bahwa kata "hudan" pada Q.S. al-Baqarah/2: 2 sama maknanya dan kandungannya pada ayat-ayat lain yang disebutkan di atas. Di samping aspek munasabah ayat, maka yang terpenting juga dalam tafsir metode tahlili adalah mengemukakan arti kosa kata ayat, asbab alnuzul pendapat Nabi SAW., atau sahabat, atau tabi' in, atau penafsir lain. ${ }^{34}$

Selanjutnya, mengenai pengungkapan penafsiran yang dilakukan oleh Nabi SAW, atau sahabat, atau para tabi' in atau ahli tafsir lainnya. Oleh TM. Hasbi, juga melakukan hal yang demikian. Dalam hal ini, ketika ia menjelaskan ayat alif, lam, mim, di situ ia mengatakan bahwa para mufassir mempunyai beberapa pendapat dalam memberikan makna terhadap ayat ini. Misalnya, ada yang berpendapat ia merupakan ayat mutasyabih dan pendapat lain menyatakan ia sebagai pembuka surah..$^{35} \mathrm{Di}$ sini, secara jelas TM. Hasbi meramu berbagai pendapat, kemudian ia juga menyatakan pendapatnya sendiri di akhir tafsirannya.

Berdasar pada uraian-uraian dan hasil analisis seperti yang dipaparkan di atas, maka dapat dirumuskan bahwa Tafsir al-Bayan karya TM. Hasbi tersebut, termasuk sebagai karya tafsir yang menggunakan metode tafsir tahlili.

\section{Metode Penulisan dan Corak}

Tafsir al-Bayan karya TM. Hasbi sebagai salah satu karya tafsir yang menggunakan metode tahlili, tentu memiliki metode penulisan yang memiliki corak tersendiri dalam menafsirkan ayat-ayat al-Qur'an. Berdasarkan hal ini dan sesuai dengan hasil bacaan penulis, maka Tafsir al-Bayan dapat dikelompokkan sebagai karya tafsir yang penulisannya terbangun atas corak fiqhi.

Menurut T.M. Hasbi bahwa karya tafsirnya ini adalah "mengistimewakan perhatian kepada hukum-hukum yang dikandung oleh ayat". ${ }^{36}$ Sesuai dengan pernyataan tersebut, maka jelas bahwa karya Tafsir al-Bayan bercorak tafsir fighi.

Jadi, ketika TM. Hasbi menafsirkan ayatayat yang berkenaan dengan fiqhi, maka yang ditonjolkan dalam penafsirannya adalah masalah hukum yang terkandung dalam ayat tersebut. Misalnya, ketika ia menafsirkan Q.S. al-Baqarah/2: 225-228, di dalam Tafsir al-Bayan ditemukan penjelasan bahwa pada ayat 225 menerangkan tentang tidak wajibnya kaffarat. Kemudian pada ayat selanjutnya, yakni ayat 226 diterangkan bahwa ayat ini mengandung hukum ila'. Berikutnya ayat 227, dikaitkan dengan hukum hukum talak yang terdapat dalam Q.S. al-Ahzab/33: 49 dan Q.S. al-Thalaq/65: 4; dan berikutnya ayat 228, dijelaskan masalah quru' lalu, disimpulkan bahwa ayat ini mewajibkan adanya timbal balik dari masing-masing pihak. Tegasnya, wajib para isteri melayani kebutuhan-kebutuhan suaminya. ${ }^{37}$

Untuk lebih menguatkan bahwa tafsir ini bercorak fiqhi, bisa diteliti bahwa sang mufassir sangat ahli di bidang hukum Islam. Karangan beliau tentang fiqhi mendominasi karya-karya beliau (36 judul). Ini membuktikan bahwa T.M Hasbi sangat menguasai ilmu ini dan sangat wajar ketika 
dituangkan pemikiran-pemikiran fikhinya dalam penafsiran al-Qur'an.

\section{PENGARUH DAN KEDUDUKAN TAFSIR} AL-BAYAN

\section{Pengaruh Tafsir al-Bayan di Tengah- tengah Masyarakat}

Dengan munculnya Tafsir al-Bayan di tengah-tengah masyarakat, maka tidak dipungkiri bahwa karya Tafsir al-Bayan ini telah turut serta memberikan pengaruh yang sangat siginifikan di tengah-tengah masyarakat. Antara lain pengaruhnya yang sangat nampak adalah masyarakat (Islam) lebih mudah memahami ajaran agamanya dengan membaca Tafsir al-Bayan. Dikatakan demikian, karena Tafsir al-Bayan menggunakan metode tahlili sehingga memudahkan untuk memahaminya, juga sangat relavan dengan kebutuhan masyarakat.

Sebenarnya, metode Tahlili dalam menginterpretasikan ayat-ayat al-Qur'an merupakan suatu metode yang telah lama digunakan para mufassir. Hanya saja, TM. Hasbi menggunakan metode tahlili tersebut dengan gaya baru. Hal ini, sesuai dengan pernyataannya, yakni: "Sesuai dengan gaya baru dalam mentafsirkan ayat-ayat al-Qur'an, maka di samping saya menerangkan maksud ayat, saya menerangkan pula ayat-ayat yang sebanding dengan ayat yang sedang dihadapi dan ayat-ayat yang ada hubungannya dengan tafsir ayat." 38

Berdasarkan pernyataan T.M. Hasbi di atas, maka dipahami bahwa gaya baru yang dimaksudkannya adalah menerangkan ayatayat yang "sebanding" dengan ayat dan ayatayat yang ada hubungannya dengan tafsir. Kata "sebanding" yang dimaksud di sini adalah terkait dengan munasabah, yakni ia berusaha senantiasa mengkorelasikan antara satu ayat dengan ayat lainnya. Sehingga, praktis bahwa uraian-uraian dalam Tafsir alBayan tersebut mudah dipahami oleh masyarakat yang membacanya.

\section{Kedudukan Tafsir al-Bayan dalam Sejarah Perkembangan Tafsir}

Untuk mengetahui keberadaan atau kedudukan karya Tafsir al-Bayan karya T.M. Hasbi al-Siddiqi ini dalam sejarah pekembangan tafsir di Indonesia, maka terlebih dahulu harus dipahami periodesasi sejarah perkembangan tafsir di Indonesia itu sendiri, sebab melalui pemahaman terhadap hal ini akan diperoleh suatu kejelasan bahwa di periode mana karya tulis tersebut berada.

Secara sepintas telah disinggung pada uraian terdahulu bahwa sejarah perkembangan tafsir al-Qur'an di Indonesia, terdiri atas empat periodesasi perkembangan tafsir yaitu :

a) Periode klasik (abad VIII - XV M)

b) Periode tengah (abad XVI - XVIII M)

c) Periode Pramodern (abad XIX M)

d) Periode Modern (abad XX) M) ${ }^{39}$

Periode yang disebut terakhir ini disebutkan periode modern, karena abad ini memberikan kontribusi yang cukup menggembirakan dalam upaya penafsiran alQur'an, jika dibandingkan dengan periodeperiode sebelumnya. ${ }^{40}$ Selanjutnya, sejarah perkembangan tafsir pada periode modern ini dibagi lagi atas tiga kurun waktu, yaitu kurun waktu pertama (1990-1950), kurun waktu kedua (1951-1980) dan kurun waktu ketiga (1981-2000). ${ }^{41}$

Melihat pembagian kurun waktu dari periode modern yang dipaparkan di atas, sudah jelas bahwa karya Tafsir al-Bayan yang 
ditulis oleh TM. Hasbi tampaknya eksis pada kurun waktu kedua (1951-1980) dalam periode modern dari sejarah perkembangan tafsir di Indonesia. Namun, dengan eksisnya Tafsir al-Bayan pada masanya itu, oleh TM. Hasbi mengakui bahwa karyanya tersebut belum terlalu sempurna. Hal ini dapat disimak pernyataannya, yakni sebagai berikut: "Akan tetapi, walaupun saya telah berusaha menyusun terjemahan yang lengkap dengan jalan: menterjemahkan setiap lafadz dan menyebut terjemahan dari kalimat-kalimat yang ditaqdirkan, namun saya belum mengatakan bahwa terjemahan ini sudah benar-benar sempurna." ${ }^{42}$

Dengan pernyataan di atas, maka dapat dipahami bahwa pada aspek lain ternyata Tafsir al-Bayan memiliki keterbatasan. Keterbatasan yang dimaksud di sini adalah dari aspek metodologis yang belum sempurna. Misalnya, dalam masalah ayat-ayat yang mutasyabihat yang memiliki banyak kalimat-kalimat (tafsiran) yang ditaqdirkan. Memang harus diakui bahwa men-taqdir-kan atau mengkira-kirakan interpretasi ayat-ayat mutasyabihat pada makna tertentu sangat sulit dan hal inilah yang dihindari oleh TM. Hasbi. Berdasarkan periodesasi di atas, maka dapat dipahami bahwa Tafsir al-Bayan, sesungguhnya telah menambah khasanah kepustakaan tafsir di Indonesia sejak kurun waktu kedua periode modern.

\section{KESIMPULAN}

Karya Tafsir al-Bayan yang ditulis oleh TM. Hasbi al-Siddiqie, pertama kali dicetak tahun 1966 oleh penerbit al-Ma'arif Bandung. kemudian dicetak lagi pada tahun 2002 oleh Penerbit Pustaka Rizki Putra Semarang. Karya tafsir ini terdiri dari dua jilid dan keseluruhan juz serta surah dalam al-
Qur'an menjadi obyek tafsirannya. Tafsir alBayan ini, dilengkapi dengan uraian tentang sejarah jazirah Arabia; Muhammad saw; sejarah al-Qur'an; penafsiran dan penterjemahan al-Qur'an. Latar belakang munculya disebabkan dua faktor. Pertama, faktor intern, yakni sebagai upaya pengembangan Tafsir al-Nur. Kedua, faktor ekstern, yakni sebagai upaya dalam rangka penyempurnaan karya-karya tafsir lain. Tafsir al-Bayan merupakan tafsir ayat-ayat al-Qur'an secara utuh (30 juz 114 surah), dengan menggunakan metode penafsiran yang bersifat analitis, yakni metode tafsir al-tahlili. Adapun bentuk penulisannya bercorak fiqhi (hukum). Tafsir al-Bayan merupakan salah satu kitab tafsir periode modern dan dengan beredarnya karya tafsir ini secara luas, tampaknya memiliki pengaruh yang sangat signifikan di tengah-tengah masyarakat (Islam) Indonesia. Pada sisi lain karya tafsir ini telah memperkaya khazanah keilmuan tafsir, khususnya dalam priode modern perkembangan tafsir di Indonesia.

\section{CATATAN AKHIR}

1 Lihat Abu al-Fadhl Jalal al-Din al-Suyuti, al-Itqan fi 'Ulum al-Qur'an, Vol. 2. cet. 2. (Beirut: Dar al-Kutub alIlmiyah, 1991) h. 381-386

2 Lihat O.S. al-Baqarah/2: 185; O.S. 'Ali Imran /3: 4; O.S. al-Nisa/4: 174.

3 Lihat O.S. al-Baqarah /2: 4; O.S. al-A'raf/7: 203; O.S. alAnfal/8: 2.

4 Lihat O.S. al-Baqarah /2: 2; O.S. al-Isra'/17: 9; O.S. alNur/24: 34

5 Masa al-Mutaqaddimin, bermula dari abad II sampai abad VII H, atau tepatnya mulai dari tahun $150 \mathrm{H} / 782$ M sampai tahun 656 H/1258 M. Karya-karya tafsir yang lahir pada saat ini antara lain adalah; Tafsir alMuqatil karya Muqatil Ibn Sulaiman (w. 150 H); Tafsir al-Kabir karya Imam al-Bukhari (w. 256 H); Tafsir Jami' al-Bayan 'an Ta'wil al-Our'an karya al-Tabari (w. $310 \mathrm{H}$ ); Tafsir. Lihat Muhammad Husain al-'ahabi, al-Tafsir wa al-Mufassirun, Vol. I. cet. 2. (Beirut: Dar al-Kutub al'Ilmiyah, 1976), h. 204.

6 Masa al-Muta'akhirin, bermula dari abad VII sampai abad XII H, atau tepatnya mulai tahun 656 H/1258 M 
sampai tahun 1286 H/1888 M. Karya-karya tafsir yang lahir pada saat ini antara lain adalah; Tafsir Anwar al-Tanzil wa Asrar al-Ta'wil karya al-Baidawi (w. 692 H); Tafsir Mafatih al-Ghaib karya Fakhr al-Razi (w. 606); Tafsir Nazm al-Durar fi Tanasub al-Ayah wa al-Suwar karya al-Biqa'i (w. 885); Tafsir Ruh al-Ma'ani karya alAlûsi (w. 1270 H). Selengkapnya, lihat Muhammad Husain al-'ahabi, al-Tafsir wa al-Mufassirûn, h. 280294. Bandingkan dengan Ahmad al-Syirbasi, Qissat alTafsir, (Beirut: Dar al-Jil, 1978), h. 58-67

7 Masa al-'Ashr (modern), bermula dari abad XIV H/XIX M sampai sekarang, atau tepatnya mulai tahun $1287 \mathrm{H} /$ 1896 M sampai sekarang. Karya-karya tafsir yang lahir pada saat ini antara lain adalah; Tafsir al-Manar karya Muhammad Abduh (w. 1905 M) dan Muhammad Rasyid Ria (w. 1935 M); Tafsir Mahasin al-Ta'wil karya al-Oasimi (w. 1914 M); Tafsir al-Maraghi karya Ahmad Musmafa al-Maragi (w. 1952 M); Tafsir al-Qur'an alKarim karya Mahmud Syaltut (w. 1952 M).

Selengkapnya, lihat Muhammad Husain al-`ahabi, alTafsir wa al-Mufassirun.

8 Lihat Islah Gusmian, Khazanah Tafsir di Indonesia; dari Hermeneutika Hingga Ideologi. cet. I, (Jakarta: Teraju, 2003), h. 65; Ferry Muhammadsyah Siregar, The Role of Religious Leaders in the Study of Tafsir in Indonesia: Case Study of Three Pesantrens in Yogyakarta from Sociological and Exegetical Perspective, Dissertation, (Yogyakarta: Sekolah Pascasarjana UGM), h. 164-165. Juga bandingkan Howard M. Federspiel, Popular Indonesian Literature of Al-Qur'an, terjemah oleh Drs. Tajul Arifin, MA, Kajian al-Qur'an di Indonesia, cet. I, (Bandung: Penerbit Mizan, 1996), h. 137

9 Nama atau istilah "Tengku" di sini merupakan laqab (gelar) terhormat yang hanya boleh dipakai oleh keturunan Maharaja Mangkubumi di Lohokseumawe. Dengan laqab ini, maka dapat diketahui bahwa TM. Hasbi Ash-Shiddieqy adalah termasuk keturunan raja dan bangsawan yang terpandang. Sedangkan "AshShiddieqy" merupakan nisbat (sandaran) dari Khalifah Abû Bakar Ash-Shiddiq. Dalam hal ini, TM. Hasbi AshShiddieqy berhak menyandarkan namanya pada "Ash Shiddieqy" karena dari silsilahnya, ia merupakan keturunan ke-37 dari Abû Bakar Ash-Shiddieqy. Lihat, Baso Midong, Riwayat Hidup TM. Hasbi Ash-Shiddieqy, Tesis magister, Kualitas Hadis Tafsir Al-Nur Karya TM. Hasbi Ash-Shiddieqy, (Ujungpandang: PPS IAIN Alauddin, 1994), h. 27.

10 Nama asli Sri Maharaja Mangkubumi adalah Abdul Hamid. la mendirikan dan menjadi ketua pertama cabang Sarikat Islam sejak didirikan di Lhokseumawe pada tahun 1916. Lihat Nourouzzaman Siddiqi, Fiqh Indonesia: Pengagas dan Gagasannya, cet. I. (Yogyakarta: Pustaka Pelajar, 1997), h. 3.

11 Nourouzzaman Siddiqi, Figh Indonesia: Pengagas dan Gagasannya, h. 14
12 Nourouzzaman Siddiqi, Fiqh Indonesia: Pengagas dan Gagasannya, h. 13-14.

13 Lihat www.oRido.wordpress.com., Ibnu Mubhar. Kontribusi TM. Hasbi al-Siddiqi dalam Kajian Hadis di Indonesia, diakses pada tanggal 3 Desember 2010

14 Baso Midong, Riwayat Hidup TM. Hasbi Ash-Shiddieqy.

15 Peralihan status PTAIN Sunan Kalijaga ke IAIN Sunan Kalijaga yang dilakukan berdasar-kan Keputusan Presiden No. 11 Tahun 1960, tiga jurusan (Syari'ah, Tarbiyah, Dakwah) pada PTAIN masing-masing dijadikan fakultas. Hanya Dakwah tetap berstatus jurusan pada Fakultas Ushuluddin. Selanjutnya, peralihan status IAIN Sunan Kalijaga menjadi UIN sekarang ini sepengetahuan penulis pada tahun 2003.

16 Baso Midong, Riwayat Hidup TM. Hasbi Ash-Shiddieqy, h. 28

17 Nourouzzaman Siddiqi, Fiqh Indonesia: Pengagas dan Gagasannya, h. 28-29

18 Nourouzzaman Siddiqi, Fiqh Indonesia: Pengagas dan Gagasannya, h. 60. Lihat pula Baso Midong, Riwayat Hidup TM. Hasbi Ash-Shiddieqy.

19 Lihat www.oRido.wordpress.com., Ibnu Mubhar. Kontribusi TM. Hasbi al-Siddiqi dalam Kajian Hadis di Indonesia, diakses pada tanggal 3 Desember 2010

20 T.M. Hasbi Ash Shiddieqy, Tafsir al-Bayan, Vol. II. cet.I. edisi 2. (Semarang: Pustaka Rizki Putra, 2002), h. 1660.

21 Tafsir al-Nûr merupakan karya tafsir yang disusun oleh TM. Hasbi al-Siddiqi yang terinspirasi oleh Tafsir alMaraghi. Sistematikan penafsiran Tafsir al-Nûr adalah dengan mengemukakan ayat-ayat yang akan ditafsirkan satu, dua, tiga dan kadang-kadang lebih dengan urutan sesuai dengan susunan kitab Mushaf Uœemani. Lihat TM. Hasbi Ash-Shiddieqy, Tafsir al-Nur, cet.l. (Jakarta: Bulan Bintang, 1965), h. 8-9

22 Lihat Islah Gusmian, Khazanah Tafsir di Indonesia; dari Hermeneutika Hingga Ideologi, h. 32 dan 49.

23 T.M. Hasbi Ash-Shiddieqy, "Pembuka Kata" dalam Tafsir al-Bayan, vol. I. h. xi

24 T.M. Hasbi Ash-Shiddieqy, "Pembuka Kata" dalam Tafsir al-Bayan, vol. I. h. Xi

25 TM. Hasbi Ash-Shiddieqy, Tafsir al-Bayan, Vol. II. h. 9

26 TM. Hasbi Ash-Shiddieqy, Tafsir al-Bayan, Vol. II. h. 1011

27 Metode Tahlili adalah suatu metode tafsir yang bermaksud menjelaskan kandungan ayat-ayat alQur'an dari seluruh aspeknya dengan memperhatikan runtut ayat-ayat al-Our'an sebagaimana yang tercantum dalam mushaf, misalnya dari aspek pengertian kosa kata, asbab al-nuzul, munasabah, syarh ayat dan selainnya. Lihat Abd. al-Hayy al-Farmawi, alBidayat fi al-Tafsir al-Maudhu'i, terjemah oleh Siryan A. Jamrah, Metode Tafsir Maudhu'i, cet. I. (Jakarta: LSIK dan PT. Raja Grafindo Persada, 1994), h. 12.

28 Metode lijmali adalah suatu metode tafsir yang 
menafsirkan ayat-ayat al-Qur'an dengan cara mengemukakan makna-makna global. Dalam sistematika uraiannya, penafsir membahas ayat-ayat demi ayat sesuai dengan susunan yang ada dalam mushaf. Lihat Abd. al-Hayy al-Farmawi, al-Bidayat $f i$ al-Tafsir al-Maudhu'i, h. 29

29 Metode Muqaran adalah suatu metode tafsir yang mengemukakan penasiran ayat-ayat al-Our'an yang ditulis oleh sejumlah mufassir, kemudian ia membandingkan arah dan kecenderungan masingmasing mufassir. Lihat Abd. al-Hayy al-Farmawi, alBidayat fi al-Tafsir al-Maudhu'i, h. 30

30 Metode Maudhu'i adalah suatu metode tafsir yang menghimpun ayat-ayat al-Our'an yang mempunyai maksud sama dalam arti sama-sama membicarakan satu topik masalah dan menyusunnya berdasarkan kronologi serta sebab turunnya ayat-ayat tersebut. Lihat Abd. al-Hayy al-Farmawi, al-Bidayat fi al-Tafsir al-Maudhu'i, h.36. Lihat juga Ferry Muhammadsyah Siregar. Nasr Hamid Abu Zayd on Tafsir, Ta'wil, and Quranic Hermeneutic Discourses: A Linguistic Perspective, Germany LAP. (2011), h. 27-36.

31 Lihat Nashruddin Baidan, Perkembangan Tafsir Al-Qur'an di Indonesia, cet. I. (Solo: Tiga Serangkai, 2003), h. 31

32 Munasabah adalah kemiripan-kemiripan yang terdapat pada hal-hal tertentu dalam al-Qur'an baik surah maupun ayat-ayat-ayatnya yang menghubungkan uraian satu dengan lainnya. Aspek munasabah dalam berbagai ayat dalam al-Qur'an dapat ditemui dalam hal-hal berikut: (a) hubungan antara satu kalimat lain dalam satu ayat; (b) hubungan antara satu ayat dengan ayat yang lain dalam banyak ayat; hubungan antara satu ayat dalam surah dengan ayat pada surah yang lain. Uraian lebih lanjut, lihat Manna' al-Oattan, Mabahis Fi 'Ulum al-Qur'an, (Beirut: Mansyurat li al-Asr al-Hadis, 1973), h. 61.

33 Hasbi Ash-Shiddieqy, Tafsir al-Bayan, vol. II, h. 1096.

34 Abd. al-Hayy al-Farmawi, al-Bidayat fi al-Tafsir alMaudhu'i, h. 12.

35 Abd. al-Hayy al-Farmawi, al-Bidayat fi al-Tafsir alMaudhu'i, h. 185.

36 Hasbi Ash-Shiddieqy, Tafsir al-Bayan., vol..l. h. xv

37 Hasbi Ash-Shiddieqy, Tafsir al-Bayan., vol.I. h. 86-87.

38 Hasbi Ash-Shiddieqy, Tafsir al-Bayan, vol.I. dalam "Pembuka Kata", h. xi

39 Nashruddin Baidan, Perkembangan Tafsir Al-Qur'an di Indonesia, h. 32-81.

40 Nashruddin Baidan, Perkembangan Tafsir Al-Qur'an di Indonesia, h. 81

41 Nashruddin Baidan, Perkembangan Tafsir Al-Qur'an di Indonesia, h. 82

42 Hasbi Ash-Shiddieqy, Tafsir al-Bayan., vol. I. dalam "Pembuka Kata", h. xi

\section{DAFTAR PUSTAKA}

'Attar Al-, Dawud. 1994. Mu'jaz 'Ulûm al-Qur'an, diterjemahkan oleh Afif Muhammad dan Ahsin Muhammad dengan judul Perspektif Baru Ilmu Al-Qur'an. cet. I. Bandung: Pustaka Hidayah

Baidan, Nashruddin. 2003. Perkembangan Tafsir Al-Qur'an di Indonesia. cet. I. Solo: Tiga Serangkai.

Departemen Agama RI, 1992. Al-Quraan dan Terjemahnya. Surabaya: Mahkota

Farmawi, Al- 1994. Abd. al-Hayy. al-Bidayat fi al-Tafsir alMaudû'i, terjemah oleh Siryan A. Jamrah dengan judul Metode Tafsir Maudhui. cet. I. Jakarta: LSIK dan PT. Raja Grafindo Persada

Federspiel, Howard, 1996. Popular Indonesian Literature of the Qur'an, terjemah oleh Drs. Tajul Arifin, MA. Dengan judul Kajian Al-Qur'an di Indonesia. cet I. Bandung: Penerbit Mizan

Gusmian, Islah. 2003. Khazanah Tafsir di Indonesia; dari Hermeneutika Hingga Ideologi. cet. I. Jakarta: Teraju

Midong, Baso. 1994. Riwayat Hidup TM. Hasbi Ash-Shiddieqy dalam "Tesis Magister" yang berjudul, Kualitas Hadis Tafsir Al-Nur Karya TM. Hasbi Ash-Shiddiegy. Ujungpandang: PPS IAIN Alauddin

Qattan, Al- Manna'. 1973. Mabahis Fi 'Ulum al-Qur'an. Beirut: Mansyurat li al-Asr al-Hadiœ

Shiddieqy, TM. Hasbi Ash-. 1993. Ilmu-Ilmu Al-Qur'an; Media-media Pokok dalam Menafsirkan Al-Qur'an. Cet. III; Jakarta: Bulan Bintang . 2002. Tafsir al-Bayan. Jilid I dan II. Semarang: Pustaka Rizki Putra Ma'arif

Shiddiqi, Nourouzzaman. 1997. Fiqh Indonesia: Pengagas dan Gagasannya Cet. I; Yogyakarta: Pustaka Pelajar

Shihab, H.M. Quraish. 1997. Tafsir al-Qur'an al-Karim. Cet.l; Bandung: Pustaka al-Hidayah

Syirbasi, Ahmad Al-. 1978. Qissat al-Tafsir. Beirut: Dar al-Jil Siregar, Ferry Muhammadsyah. 2011. Nasr Hamid Abu Zayd on Tafsir, Ta'wil and Quranic Hermeneutic Discourses: A Linguistic Perspective. Germany: LAP . 2014. "The Role of Religious Leader in the Study of Tafsir in Indonesia: Case Study of Three Pesantrens in Yogyakarta from Sociological and Exegetical (Tafsir) Perspective." Dissertation. Yogyakarta: ICRS-The UGM Graduate School

Zahabi, Muhammad Husain, Al-. 1976. al-Tafsir wa alMufassirun, Vol. I. cet. II. (t.t). Beirut: Dar al-Kutub al'Ilmiyah 